\title{
To Evaluate the Stability of Carbopol 934 based Transdermal Gel of Paracetamol Nanocapsules
}

\author{
Jayanti Mukherjee $^{1 *}$, Shivani Khoware ${ }^{1}$ and Sheetal Bhasin ${ }^{2}$ \\ ${ }^{1}$ Department of Pharmaceutical Chemistry, Shri Bherulal Pharmacy Institute, Indore, India \\ ${ }^{2}$ Department of Microbiology, Maharaja Ranjit Singh College, Indore, India \\ *Corresponding author
}

\begin{tabular}{l} 
K e y w o r d s \\
Paracetamol \\
nanocapsules, \\
Accelerated \\
Stability Test, \\
Microbiological \\
tests for organisms, \\
Stability \\
\hline Article Info \\
\hline $\begin{array}{l}\text { Accepted: } \\
\text { 29 March } 2020 \\
\text { Available Online: } \\
\text { 10 April } 2020\end{array}$
\end{tabular}

\section{Keywords}

Paracetamol nanocapsules, Microbiological tests for organisms, Stability

Article Info

Accepted: Available Online: 10 April 2020

\section{A B S T R A C T}

The nanocapsules were prepared by the interfacial deposition technique proposed in the year 1989. The required quantity of the drug and benzyl benzoate were mixed and added dropwise in the organic phase containing the polymer PLGA dissolved in the two organic solvents. With continuous stirring at 4000rpm for 1 hour, soyalecithin was added in the above mixture. Finally, the later was added in the solution of Polaxamer 188 with a continuous stirring speed of 4000rpm for 30 minutes. Fine concentrated colloidal dispersion of paracetamol nanocapsules were obtained after the removal of organic solvents and high-speed centrifugation. Then anocapsules were characterized by scanning electron microscopy, zeta potential and particle size analysis. The compatibility of the excipients was analysed by FTIR. The nanogel of paracetamol was formulated with carbopol 934 and triethanolamine as the major ingredients. The transdermal formulation was tested for its in vitro permeation studies through the biomimetic dialysis membrane using Franz diffusion cell and entrapment efficiency was also conducted. The receiver solution was phosphate buffer ( $\mathrm{pH} 7.4)$ and the permeability study was carried out for 12 hours. The transdermal gel was subjected to accelerated stability tests for 6 months and after this period microbiological tests were performed for common microorganisms. The qualitative and quantitative estimation of viable microorganisms present in the gel was evaluated which includes tests for total viable count (bacteria and fungi) and specified microbial organisms (Escherichia coli, Salmonella typhi, Pseudomonas aeruginosa and Staphylococcus aureus). The accelerated stability study showed that the product is stable for the period of 6 months. The microbiological assay established the absence of common microorganisms. Transdermal gel formulation containing paracetamol can be prepared by the interfacial deposition technique using Carbopol 934 as a carrier. In vitro drug release data showed better physiochemical characteristics with no skin irritation reactions. Moreover, the accelerated stability test and the microbiological tests assured a stable product. 


\section{Introduction}

Over the last decade the application of nanotechnology to medicine is completely reshaping our idea of therapy. This exciting interdisciplinary field lies at the intersection of different research areas such as engineering, biotechnology, and material science. Novel nanocarriers are being developed to sidestep fundamental problems of traditional drugs based on their ability to overcome poor water solubility issues, improve physical/chemical stability, enhance bioavailability and alter unacceptable toxicity profiles.

Drug delivery from colloidal systems such as nanocapsules dispersed in a gel appears to be unique when compared to the delivery from traditional topical and dermatological formulations. During the last decade, considerable attention has been paid to the development of new controlled delivery systems, in order to produce a long-term drug release and, therefore, increasing patient's therapeutic compliance and acceptance. The transdermal drug delivery system of NSAIDS can be used to deliver drug for the treatment of acute and chronic pain and inflammation. Osteoarthritis, rheumatoid arthritis and ankylosing spondylitis are a group of related, but distinct, disorders of the cartilage of osteoarticular joints. NSAIDS are in use to reduce the pain and inflammation.

Their main benefit derives from their antiinflammatory and analgesic effect, but the use of these agents orally is not innocuous since their regular use may lead to chronic side effects such as gastric irritation to severe bleeding and ulceration of gastric region due to both inhibition of synthesis of prostaglandins and direct contact of the drug with mucosa. Since long-term NSAID treatment is indicated for such illnesses, the ideal agent should have good efficiency and a low propensity to cause adverse events. Therefore, recent focus of the researchers has been to deliver such potential NSAIDs in a controlled manner in the transdermal dosage form that will minimize its release in stomach and thereby overcoming its chronic adverse effect. $^{1}$

The microbial instability of pharmaceutical and cosmetic products is a crucial parameter in evaluating product quality and performance. Such instability may lead to alteration of the physicochemical properties of the product, which in turn may affect the shelf-life of the product or may become life threatening in certain cases ${ }^{(2)}$. Microbial instability affects both sterile and nonsterile dosage forms.

A wide range of preservatives and combinations of preservatives are used to counter microbial instability in pharmaceutical and cosmetic products. It has been reported that microbes have developed resistance to these preservatives in some cases (3). One of the novel and alternate approaches for minimizing microbial instability of a product is by controlling the water activity of the product. In this review, we summarize all the aspects related to the stability of the products, from the sources of contamination, to the processing condition, the prevention methods, how the microorganism can develop resistance to preservatives, and new approaches to this matter ${ }^{14-16}$.

Appearance happens to be one of the important organoleptic properties of pharmaceuticals and particularly cosmetics. Microbial contamination can bring about a significant impact on the visual appearance of the pharmaceuticals and cosmetics which results in poor patient compliance. These changes might also result in deviation from the targeted pharmacokinetics compromising patient health and safety ${ }^{(4)}$. Microbial attack 
of pharmaceuticals and cosmetics can lead to changes in the biological activity of the active ingredients such as loss of activity or deleterious effects due to formation of toxic products ${ }^{(5)}$. Based on the intended usage, cosmetic products include excipients such as alcohol, waxes, lipids, polysaccharides, vitamins, and proteins, which are also nutrients for microbial growth (6). Some cosmetics may cause slight trauma in the area of application, which can increase the risk of microbial infection ${ }^{(7)}$.

Although the use of GMPs and preservatives restricts microbial growth, many cosmetic products are still reported for microbial contamination ${ }^{(8)}$. According to the notes of guidance for cosmetic products issued by the Scientific Committee on Consumer Products (SCCP), there are two different categories of cosmetic products: (a) products for children under 3 years old or products to be applied to the eye area or mucous membranes and (b) other cosmetic products.

Products in category 1 should contain no more than 102 CFUs of aerobic mesophilic microorganisms per milliliter or gram, and for other products, the limit is 103 CFUs per milliliter or gram. For category 2 products, $E$. coli, $P$. aeruginosa, $S$. aureus, and $C$. albicans must not be detectable in $0.1 \mathrm{ml}$ or $0.5 \mathrm{~g}$ and in $0.1 \mathrm{ml} /$ or $\mathrm{g} / \mathrm{ml}$ of the product ${ }^{(8,17)}$.

Trying to give our own piece of contribution to this area of research, here devoted the efforts toward the formulation of carbopol 934 based transdermal gel of paracetamol nanocapsules. Stability studies are considered as pre-requisites for the acceptance and approval of any pharmaceutical products. The objective of present investigation was to study the stability of the carbopol based transdermal gel of paracetamol nanocapsules. The gel under study was stored on processed primary pack at elevated stress condition i.e. temperature and humidity. The physicochemical and microbiological parameters were monitored throughout the study at predefined time intervals ${ }^{(8)}$.

\section{Materials and methods of nanogel formulation}

All the materials used were of analytical grade and procured from commercial sources. These are BenzylBenzoate from Loba Chemic Pvt. Ltd, Soya lecithin liquid and Poloxamer 188from Hi-Media Labs, Mumbai; Poly(D,Llactide-co-glycolide) from Sigma Aldrich, Paracetamol API, methanol, ethanol, acetone and dichloromethane from Loba Chemic Pvt. Ltd.

Paracetamol were prepared by the interfacial deposition technique proposed by Fessiet $a l^{(9)}$. The nanocapsules are essentially an oil-inwater emulsion type. $50 \mathrm{mg}$ of the polymer was dissolved in $50 \mathrm{~mL}$ solution containing equal quantity of acetone and ethyl alcohol at stirring speed of $4000 \mathrm{rpm}$ for about 30 minutes that formed the organic phase. 100 $\mathrm{mg}$ of soya lecithin liquid was added to the above organic phase maintaining the stirring speed for about an hour. $100 \mathrm{mg}$ of the drug was dissolved in $3 \mathrm{~mL}$ of benzyl benzoate was then added dropwise to the above organic mixture.

The stirring was maintained for about an hour. This organic mixture was then progressively added dropwise $(1 \mathrm{~mL} / \mathrm{min})$ through a syringe $(0.22 \mathrm{~mm})$ attached to a burette to distilled water $(50 \mathrm{~mL})$ containing poloxamer 188 as the stabilizer under constant stirring of about $4000 \mathrm{rpm}$. This was continued till a fine colloidal dispersion of nanocapsules was formed due to Tyndall effect. Organic solvent (acetone) was subsequently removed by heating under reduced pressure. 
The remaining colloidal mixture was then further concentrated to about $25 \mathrm{~mL}$ by centrifugation (4000 rpm). The supernatant obtained was analyzed for the amount of the free $\operatorname{drug}^{18}$. The formulated nanocapsules were characterized with the measurement of particle size and zeta potential (Fig. 1), SEM (Fig. 2) and FTIR studies (Fig. 3). The accelerated stability study report and the microbiological study details for the common microorganisms was shown in Table 1.

\section{Methods for microbial studies}

\section{Total aerobic bacterial count}

The test was performed by pour plate method on the optimized formulation. $10 \mathrm{~g}$ gel was added to previously sterilized $90 \mathrm{ml}$ of $\mathrm{pH} 7$ buffered sodium chloride solution-peptone solution. $1 \mathrm{ml}$ of above dilution was taken into two sets (duplicate). $15-20 \mathrm{ml}$ of sterile casein soya bean digest agar which had been previously melted and cooled at $45^{\circ} \mathrm{C}$ was added to two petridishes in one set, for bacterial count. These plates were incubated at $30-35^{\circ} \mathrm{C}$ for 5 days with negative control. After incubation, the plates were observed and the number of colonies formed were counted and recorded ${ }^{10}$.

\section{Total yeast and moulds count}

15-20 ml of sterile Sabouraud's dextrose agar (previously melted and cooled at $45^{\circ} \mathrm{C}$ ) was added to two petridishes in one set for yeast and moulds count. These plates were incubated at $20-25^{\circ} \mathrm{C}$ for 5 days with negative control. After incubation, the plates were observed and the number of colonies formed were counted and recorded.

\section{Test for specific microorganisms}

Tests for specific microorganisms were performed to confirm the absence of microorganisms i.e. Escherichia coli, Staphylococcus aureus, Pseudomonas aeruginosa and Salmonella typhi in the formulated gels using proper medias ${ }^{11,12,13}$.

\section{Escherichia coli}

To $10 \mathrm{~g}$ of gel, $90 \mathrm{ml}$ of buffered sodium chloride peptone solution of $\mathrm{pH} 7$ was added. $10 \mathrm{ml}$ of this solution was inoculated with 100 $\mathrm{ml}$ of casein soybean digest broth and incubated at $35-37^{\circ} \mathrm{C}$ for $18-48$ hours. After shaking the container properly, $1 \mathrm{ml}$ was transferred to $100 \mathrm{ml}$ of MacConkey agar medium and incubated at $43-45^{\circ} \mathrm{C}$ for $18-24$ hours. Sub culturing on plates of MacConkey agar was done at $35-37^{\circ} \mathrm{C}$ for $18-72$ hours. Growth of red, non-mucoid colonies of gramnegative rods indicates possible presence of E.coli.

\section{Staphylococcus aureus}

To $10 \mathrm{~g}$ of gel, $90 \mathrm{ml}$ of buffered sodium chloride peptone solution of $\mathrm{pH} 7$ was added. $10 \mathrm{ml}$ of this solution or the quantity corresponding to $1 \mathrm{~g}$ was inoculated with $100 \mathrm{ml}$ of casein soya bean digest broth and incubated at $35-37^{\circ} \mathrm{C}$ for $18-48$ hours. Sub culturing on a plate of Baird-Parker agar was done and incubated at $35-37^{\circ} \mathrm{C}$ for $18-72$ hours. Black colonies of gram-negative cocci surrounding by a clear zone indicate the presence of $S$. aureus.

\section{Pseudomonas aeruginosa}

To $10 \mathrm{~g}$ of gel, $90 \mathrm{ml}$ of buffered sodium chloride peptone solution of $\mathrm{pH} 7$ was added. $10 \mathrm{ml}$ of this solution or the quantity corresponding to $1 \mathrm{~g}$ was inoculated with $100 \mathrm{ml}$ of casein soya bean digest broth and incubated at $35-37^{\circ} \mathrm{C}$ for $18-48$ hours. Sub culturing on a plate of cetrimide agar was done and incubated at $35-37^{\circ} \mathrm{C}$ for $18-72$ hours. This test passes if there is no growth of microorganisms. 


\section{Salmonella species}

To $10 \mathrm{~g}$ of gel, $90 \mathrm{ml}$ of casein soya bean digest broth was added and incubated 35$37^{\circ} \mathrm{C}$ for $18-24$ hours. $1 \mathrm{ml}$ of the enrichment culture was transferred to $10 \mathrm{ml}$ of Tetrathionate bile brilliant green broth and incubated at $41-43^{\circ} \mathrm{C}$ for $18-24$ hours. Sub culturing on deoxycholate citrate agar and xylose lysine deoxycholate agar was done and incubated at $35-37^{\circ} \mathrm{C}$ for $18-72$ hours. The probable presence of Salmonella was indicated by the development of red colored colonies with or without black centers.

\section{Results and Discussion}

The zeta potential was to be-9.8, with scanning electron microscopy data giving the data around $10 \mu \mathrm{m}$ and the FTIR data showed that there are no incompatibilities between the excipients used. The accelerated stability study showed that the product is stable for the period of 6 months. The microbiological assay established the absence of common microorganisms.

Total aerobic microbial count (TAMC) and Total combined yeast and mould count (TYMC) are the quantitative microbial tests in the range of not more than $1000 \mathrm{cfu}$ and 100 cfu respectively. The initial, 3 months and 6 months report showed the colony forming unit in the stipulated range, while the qualitative test for specified microorganisms like Escherichia coli, Pseudomonas aeruginosa, Staphylococcus aureus and Salmonella typhi were found to be negative.

Table.1 Stability report for prepared paracetamol nanocapsule gel

\begin{tabular}{|c|c|c|c|c|}
\hline Storage condition & \multicolumn{4}{|c|}{$40^{\circ} \mathrm{C} \pm 2^{\circ} \mathrm{Cand} 75 \% \pm \mathrm{RH}$ ( Accelerated Stability Study) } \\
\hline Product name & $\begin{array}{l}\text { Paracetamol } \\
\text { Nanoparticle gel }\end{array}$ & \multicolumn{2}{|c|}{ Pack weight } & $50 \mathrm{~g}$ \\
\hline Mgf date & $23 / 11 / 2018$ & \multicolumn{2}{|c|}{ Mgf site address } & $\begin{array}{l}\text { Shri Bherulal Pharmacy } \\
\text { Institute, Indore }\end{array}$ \\
\hline Test & Acceptance criteria & Initial & $3 \mathbf{M}$ & 6M \\
\hline Description & Light yellow color & Complies & Complies & Complies \\
\hline $\begin{array}{lr}\text { Identification } & \text { Drug } \\
\text { content by } & \text { UV } \\
\text { spectroscopy } & \end{array}$ & & $92.7 \pm 0.65$ & $89.1 \pm 0.32$ & $89.0 \pm 0.20$ \\
\hline \multicolumn{5}{|c|}{ Microbial Evaluation Tests } \\
\hline $\begin{array}{lr}\text { Total } & \text { aerobic } \\
\text { microbial } & \text { count } \\
\text { (TAMC) } & \end{array}$ & $\begin{array}{l}\text { Not more than } 1000 \\
\text { cfu/g }\end{array}$ & $\begin{array}{l}5 \quad \mathrm{cfu} / \mathrm{g} \\
\text { complies }\end{array}$ & $\begin{array}{l}23 \quad \mathrm{cfu} / \mathrm{g}, \\
\text { complies }\end{array}$ & $57 \mathrm{cfu} / \mathrm{g}$, complies \\
\hline $\begin{array}{l}\text { Total combined yeast } \\
\text { and mould count } \\
\text { (TYMC) }\end{array}$ & Not more than $100 \mathrm{cfu} / \mathrm{g}$ & $\begin{array}{l}10 \mathrm{cfu} / \mathrm{g} \\
\text { Complies }\end{array}$ & $\begin{array}{l}27 \quad \mathrm{cfu} / \mathrm{g}, \\
\text { complies }\end{array}$ & $38 \mathrm{cfu} / \mathrm{g}$, complies \\
\hline \multicolumn{5}{|c|}{ Test for Specified Microorganisms } \\
\hline Escherichia coli & Should be absent /g & Absent & Absent & Absent \\
\hline $\begin{array}{l}\text { Pseudomonas } \\
\text { aeruginose }\end{array}$ & Should be absent /g & Absent & Absent & Absent \\
\hline $\begin{array}{l}\text { Staphylococcus } \\
\text { aureus }\end{array}$ & Should be absent /g & Absent & Absent & Absent \\
\hline Salmonella typhi & Should be absent $/ 10 \mathrm{~g}$ & Absent & Absent & Absent \\
\hline
\end{tabular}




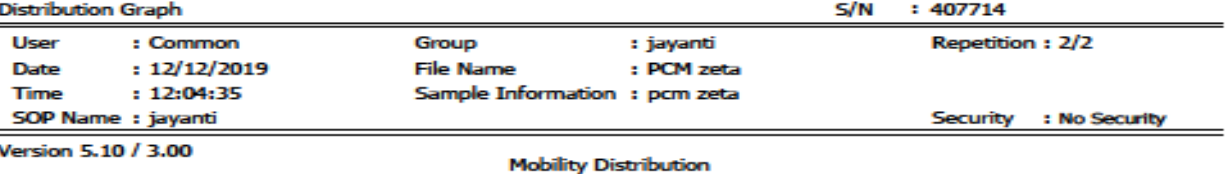

Version $5.10 / 3.00$

Mobility Distribution

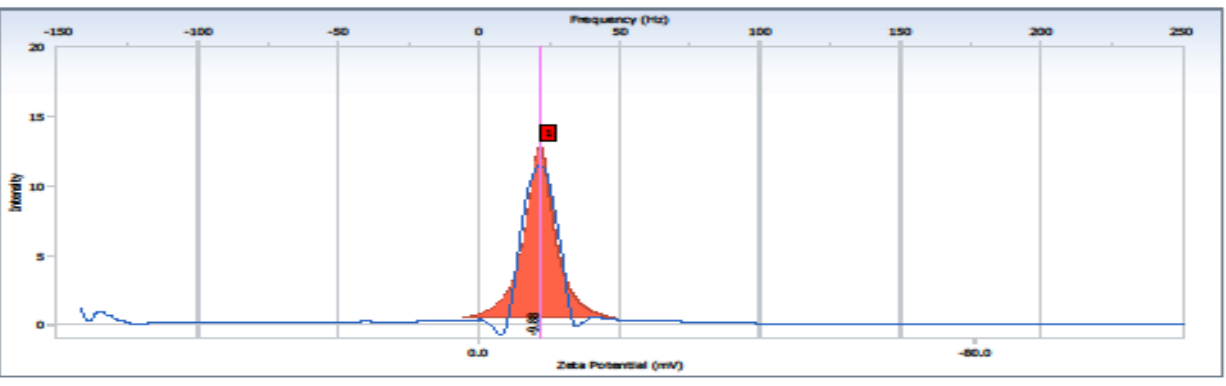

\begin{tabular}{|c|c|c|c|c|c|}
\hline \multicolumn{6}{|c|}{ Measurement Results } \\
\hline $\begin{array}{l}\text { Zeta Potential } \\
\text { Mobility } \\
\text { Conductivity }\end{array}$ & $\begin{array}{l}:-9.88 \\
:-5.364 e-005 \\
: 0.1511\end{array}$ & $\begin{array}{l}\left(\mathrm{mV}^{2}\right) \\
\left(\mathrm{cm}^{2} / \mathrm{Ns}\right) \\
(\mathrm{ms} / \mathrm{cm})\end{array}$ & $\begin{array}{l}\text { Doppler shift } \\
\text { Base Frequency } \\
\text { Conversion Equation }\end{array}$ & $\begin{array}{l}\text { : } 21.82 \\
: 124.5 \\
: \text { Smoluchowski }\end{array}$ & $\begin{array}{l}(\mathrm{Hz}) \\
(\mathrm{Hz})\end{array}$ \\
\hline $\begin{array}{l}\text { Zeta Potential of Cell } \\
\text { Upper Surface } \\
\text { Lower Surface } \\
\text { Cell Condition } \\
\text { Cell Type } \\
\text { Avg. Electric Field } \\
\text { Avg. Current }\end{array}$ & $\begin{array}{l}:-10.57 \\
:-9.60 \\
: \text { Flow Cell } \\
:-84.82 \\
:-0.64\end{array}$ & $\begin{array}{l}(\mathrm{mV}) \\
(\mathrm{mV}) \\
(\mathrm{V} / \mathrm{cm}) \\
(\mathrm{mA})\end{array}$ & $\begin{array}{l}\text { Diluent Properties } \\
\text { Diluent Name } \\
\text { Temperature } \\
\text { Refractive Index } \\
\text { Viscosity } \\
\text { Dielectric Constant }\end{array}$ & $\begin{array}{l}=\text { Methanol } \\
=25.0 \\
=1.3312 \\
=0.5470 \\
=33.6\end{array}$ & $\begin{array}{l}\left({ }^{\circ} \mathrm{C}\right) \\
\text { (CP) }\end{array}$ \\
\hline $\begin{array}{l}\text { Peak Data Table of Dist } \\
\text { Peak Frequency }(\mathrm{Hz})\end{array}$ & $\begin{array}{l}\text { ution Graph } \\
\text { Intensity } \mathrm{Ha}\end{array}$ & lalf Width $(\mathrm{Hz})$ & Zeta Potential (mV) & Mobility $\left(\mathrm{cm}^{2} / \mathrm{Ns}\right)$ & \\
\hline $\begin{array}{ll}1 & 21.82 \\
2 & \\
3 & \\
4 & \\
5 & \end{array}$ & 12.81 & 5.43 & -9.88 & $-5.364 e-005$ & \\
\hline
\end{tabular}

Fig.1 Zeta potential report

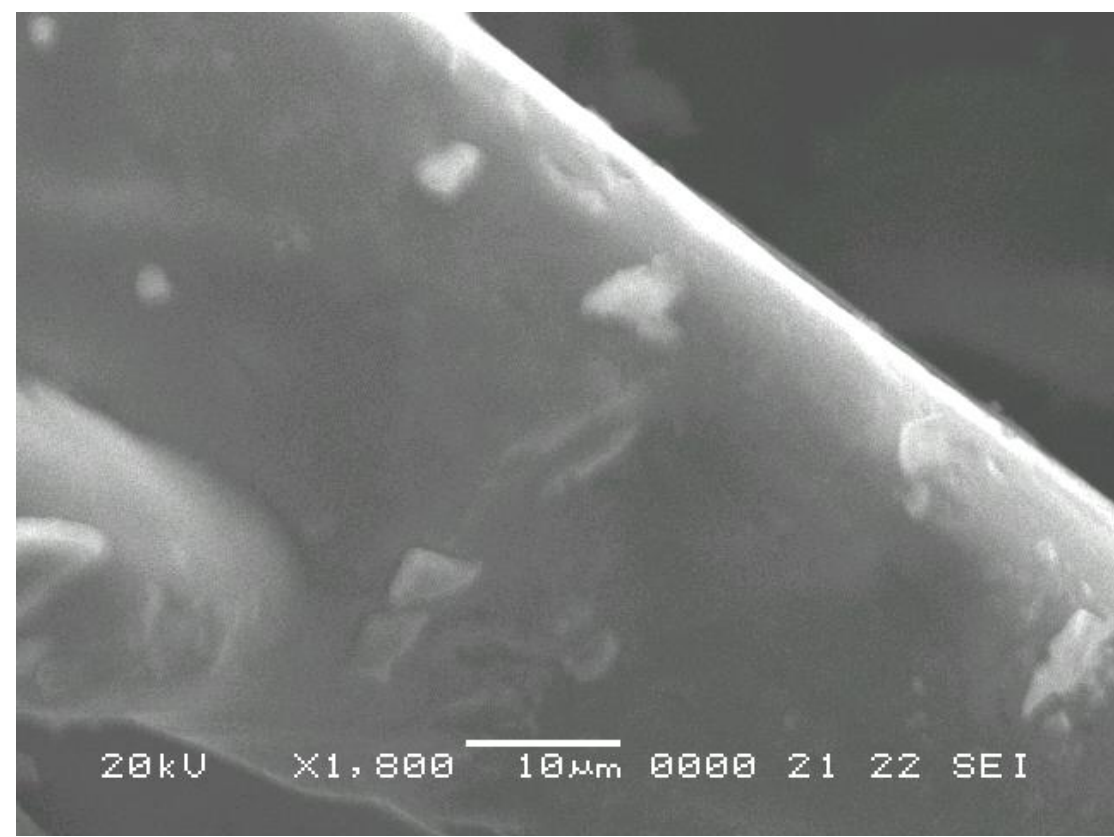

Fig.2 SEM report for the paracetamol nanocapsules 


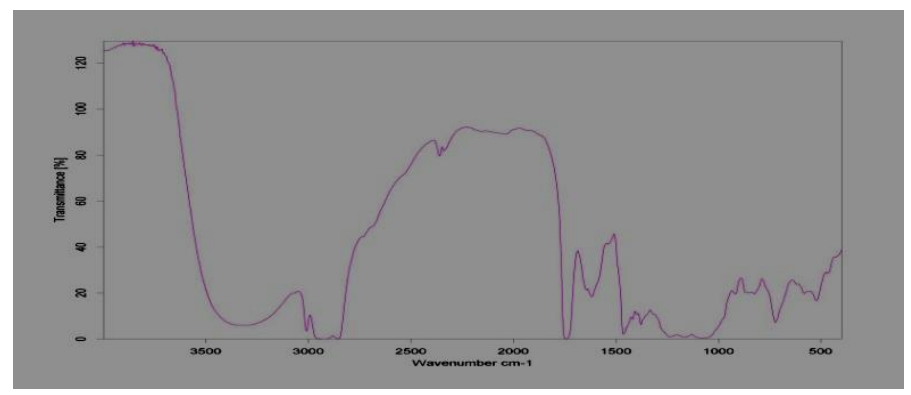

Fig.3 FITR of benzyl benzoate

Transdermal gel formulation containing paracetamol can be prepared by the interfacial deposition technique using Carbopol 934 as a carrier. In vitro drug release data showed better release pattern, better physiochemical characteristics with no skin irritation reactions. Moreover, the accelerated stability test and the microbiological tests assured a stable product.

\section{Acknowledgement}

We highly acknowledge the cooperation of $\mathrm{Dr}$ Uday Deshpande, Dr Phase, Dr G N Okram and Centre director Dr A Banerjee of UGC, DAE Consortium for their enormous support to use their laboratories for instrumental facilities. We are thankful to the management of Maharaja Ranjit Singh College for their extended support in conducting the microbiological studies.

\section{References}

1. Adriana RP, Letıcia SF, Rodrigo PS, Alberto MD, Edilson VB, Tania MHC, et al; sodium diclofenac: A new strategy to control the release of drugs. Int J Pharm, 2008; 358(1-2); 292-295

2. Bajaj S, Singla D, Sakhuja N. Stability testing of pharmaceutical products. Journal of Applied Pharmaceutical Science 2012; 3: 129- 138.

3. Huynh Ba K, Zahn M. Understanding ICH guidelines applicable to stability testing. In; Huynh Ba K. Handbook of stability testing in pharmaceutical development: regulations, methodologies and best practices. New York: Springer science and business media; 2009, 21-41.

4. Magari RT. Assessing shelf life using Real-Time and Accelerated stability tests. Biopharma International; 2003.

5. Dawar N, Arora M, Naved T, Tyagi VK. Stability studies of formulation containing Eucalyptus oil. Indo Global Journal of Pharmaceutical Sciences 2013; 3: 174-180.

6. Malik A, Kumar V, Renu, Sunil, Kumar T, World Health Organization's Guidelines for stability testing of pharmaceutical products. Journal of Chemical and Pharmaceutical Research 2011;3 (2); 892-898.

7. British Pharmacopoeia, Appendix XVI B, Microbiological Examination of NonSterile Products; 2012.

8. British Pharmacopoeia, Appendix XVID, Microbiological quality of Non-Sterile pharmaceutical preparations and substance; 2012.

9. Fessi H, Puisieux F, Devissaguet $\mathrm{Ph}$, Ammoury N, Benita S. Nanocapsule formation by interfacial polymer deposition following solvent displacement: International Journal of Pharmaceutics. 1989; 55(1): R1-R4.

10. Bisno AL, Gerber MA, Kaplan EL, Schwartz RH, et al Diagnosis and management of group A streptococcal pharyngitis: A practice guideline. Clin Infect Dis. 1997;25(3):574-83.

11. Harrison LA. Microbial degradation of cellulose polymers used in cosmetics and 
toiletries. Int J Cosmet Sci. 1987; 9(2): 73-84.

12. Kokura S, Handa O, Takagi T, Ishikawa T, Naito Y, Yoshikawa T. Silver nanoparticles as a safe preservative for use in cosmetics. Nanomedicine Nanotechnology Biol Med. 2010; 6(4): $570-4$.

13. Smart R, Spooner DF. Microbiological spoilage in pharmaceuticals and cosmetics. J Soc Cosmet Chem. 1972; 23: $721-37$.

14. Elmorsy TH, Hafez EA. Microbial contamination of some cosmetic preparations in Egypt. J Agric Technol. 2016; 12(3): 567-77.

15. Neza E, Centini M. Microbiologically contaminated and over preserved cosmetic products according Rapex
2008-2014. Cosmetics. 2016; 3(1): 3.

16. Shaqra QMA, Al-Groom RM. Microbiological quality of hair and skin care cosmetics manufactured in Jordan. Int Biodeterior Biodegrad. 2012; 69: 6972.

17. Hugbo PG, Onyekweli AO, Igwe I. Microbial contamination and preservative capacity of some brands of cosmetic creams. Trop J Pharm Res. 2003; 2(2): 229-34.

18. Redhead HM, Davis SS and IllumL. 2001 Drug delivery in poly (lactide-coglycolide) nanoparticles surface modified with poloxamer 407 and poloxamine 908 : in vitro characterization and in vivo evaluation. J Control Release, 70(3): 35363

\section{How to cite this article:}

Jayanti Mukherjee, Shivani Khoware and Sheetal Bhasin. 2020. To Evaluate the Stability of Carbopol 934 based Transdermal Gel of Paracetamol Nanocapsules. Int.J.Curr.Microbiol.App.Sci. 9(04): 3097-3104. doi: https://doi.org/10.20546/ijcmas.2020.904.361 